\title{
ANALISIS RISIKO PRODUKSI CABAI BESAR DI KECAMATAN SIKUR KABUPATEN LOMBOK TIMUR
}

\section{RISK ANALYSIS OF LARGE CHILI PRODUCTION IN SIKUR DISTRICT EAST LOMBOK REGENCY}

\author{
Silvia Devi Kharisma Putri ${ }^{1}$, Amiruddin ${ }^{2}$, Abdullah Usman $^{3}$ \\ ${ }^{1,2,3}$ Program Studi Agribisnis, Universitas Mataram, Kota Mataram, Indonesia \\ *Email Penulis Korespondensi: silviasdkp@gmail.com
}

\begin{abstract}
ABSTRAK
Penelitian ini bertujuan untuk: (1) mengetahui produksi pada usahatani cabai besar di KecamatanSikur Kabupaten Lombok Timur; (2) menganalisis risiko produksi pada usahatani cabai besar di Kecamatan Sikur Kabupaten Lombok Timur; (3) menganalisis faktor-faktor yang mempengaruhi risiko produksi pada usahatani cabai besar di Kecamatan Sikur Kabupaten Lombok Timur; (4) menentukan rekomendasi penanganan risiko produksi pada usahatani cabai besar di Kecamatan Sikur Kabupaten Lombok Timur. Penelitian ini menggunakan metode deskriptif. Penentuan daerah sampel dilakukan dengan metode puposive sampling. Jumlah responden ditentukan secara quota sampling sebanyak 40 orang petani cabai. Hasil penelitian menujukkan bahwa: (1) Rata-rata produksi cabai besar adalah $12.245 \mathrm{~kg} / \mathrm{ha}$; (2) Risiko produksi cabai besar tergolong tinggi dengan nilai koefisien variasi (KV) sebesar 0,51 ; (3) Faktor-faktor yang meningkatkan risiko produksi positif atau opportunity yaitu pupuk kandang, zat pengatur tumbuh, dan intensitas pengairan. Sedangkan bibit, pupuk kimia, dan intensitas serangan HPT merupakan faktor-faktor yang menurunkan risiko produksi positif atau opportunity. Faktor-faktor yang meningkatkan risiko produksi negatif yaitu pupuk kimia, intensitas pengairan, dan intensitas serangan HPT. Sedangkan bibit, pupuk kandang, dan zat pengatur tumbuh merupakan faktorfaktor yang menurunkan risiko produksi negatif. Rekomendasi penanganan risiko produksi untuk meningkatkan risiko produksi positif (opportunity) yaitu dengan mengurangi jumlah penggunaan bibit, pupuk kimia, meningkatkan jumlah penggunaan pupuk kandang, zat pengatur tumbuh, intensitas pengairan, dan melakukan pengendalian HPT dengan baik. Sedangkan rekomendasi untuk mengurangi risiko produksi negatif yaitu dengan meningkatkan jumlah penggunaan bibit, pupuk kandang, zat pengatur tumbuh, mengurangi jumlah penggunaan pupuk kimia, intensitas pengairan, dan melakukan pengendalian HPT dengan baik.
\end{abstract}

Kata Kunci : Risiko, Produksi, Usahatani Cabai Besar

\begin{abstract}
This study aims to: (1) determine the production of large chili farming in Sikur Subdistrict, East Lombok Regency; (2) analyzing production risk in large chili farming in Sikur District, East Lombok Regency; (3) analyzing the factors that affect production risk in large chilli farming in Sikur District, East Lombok Regency; (4) determine recommendations for handling production risks in large chili farming in Sikur District, East Lombok Regency. This research uses a descriptive method. Determination of the sample area is done by puposive sampling method. The number of respondents was determined by a quota sampling of 40 chilli farmers. The results showed that: (1) The average large chili production was 12,245 $\mathrm{kg} / \mathrm{ha}$; (2) The risk of large chili production is relatively high with a coefficient of variation (CV) of 0.51 ; (3) Factors that increase the risk of positive production or opportunity are manure, growth regulators, and irrigation intensity. Whereas seeds, chemical fertilizers, and the intensity of HPT attacks are factors that reduce the risk of positive production or opportunity. Factors that increase the risk of negative production are chemical fertilizers, irrigation intensity, and pest plant disease attack intensity. Whereas seeds, manure, and growth regulators are factors that reduce the risk of negative production. Recommendations for handling production risks to increase the risk of positive production (opportunity), namely by reducing the amount of use of seeds, chemical fertilizers, increasing the amount of use of manure, growth regulators, irrigation intensity, and controlling pest plant disease properly. Whereas recommendations to reduce the risk of negative production are to increase the amount of use of seeds, manure, growth regulators, reduce the amount of use of chemical fertilizers, irrigation intensity, and control pest plant disease properly.
\end{abstract}

Keywords : Risk, Production, Big Chili Farming

Putri, S.D.K., Amiruddin, dan Usman, A. 


\section{PENDAHULUAN}

Salah satu sub sektor pertanian yang menjadi pusat perhatian dan sangat potensial untuk dikembangkan adalah sub sektor hortikultura. Menurut Irsan (2010) dalam pengembangan sub sektor hortikultura dibedakan atas buah-buahan, tanaman hias, sayur-sayuran, dan tanaman obat-obatan. Diantara subsektor horikultura tersebut, usaha tani sayuran memberi kontribusi penting bagi ketahanan pangan dan gizi masyarakat (Septiadi dan Nursan, 2020). Disisi lain, peningkatan nilai impor pada sub sektor hortikultura mengindikasikan adanya kegagalan dalam memenuhi permintaan dalam negeri sehingga melakukan impor. Berdasarkan BPS (2019) pada tahun 2017 sampai tahun 2018 impor untuk setiap sub sektor pertanian cenderung menurun, hal ini juga diikuti oleh penurunan nilai ekspor. Berbeda dengan sub sektorsub sektor yang lain, sub sektor hortikultura mengalami peningkatan nilai impor dari tahun 2017 ke tahun 2018 sebesar 16,35 persen. Peningkatan impor tersebut selain disebabkan karena permintaan konsumen domestik yang lebih menyukai produk luar negeri juga disebabkan ketidakmampuan dalam memproduksi produk-produk hortikultura dalam kuantitas dan kualitas yang diinginkan, seperti produksi menurun dan terjadinya gagal panen, serta mutu yang rendah.

Cabai merupakan produk hortikultura yang digolongkan ke dalam dua kelompok yaitu cabai besar dan cabai kecil (cabai rawit). Cabai merupakan salah satu jenis komoditas hortikultura unggulan nasional (Septiadi et al, 2020). Cabai besar merupakan jenis yang paling banyak diperdagangkan, karena selain untuk konsumsi rumah tangga cabai besar juga banyak digunakan sebagai bahan baku industri pengolahan. Berdasarkan Pusat Data dan Informasi Pertanian (2019) konsumsi cabai besar mengalami peningkatan dari 1,50 kg/kapita/tahun pada tahun 2017 menjadi 1,65 $\mathrm{kg} / \mathrm{kapita} / \mathrm{tahun}$ pada tahun 2018.

Kabupaten Lombok Timur sebagai penghasil cabai besar terbesar di Nusa Tenggara Barat tentu memiliki peranan penting dalam kontribusi pasokan cabai besar nasional. Berdasarkan BPS Kabupaten Lombok Timur (2019) Kecamatan Sembalun memiliki produksi cabai besar tertinggi di Kabupaten Lombok Timur tahun 2018 dengan produksi 3.652,8 ton yang kemudian diikuti oleh Kecamatan Jerowaru. Kecamatan Sikur merupakan salah satu sentral produksi cabai besar dengan produksi terbesar ketiga di Kabupaten Lombok Timur. Pada tahun 2018 produksi cabai besar di Kecamatan Sikur sebanyak 1.306,9 ton, tetapi besarnya jumlah produksi cabai besar di Kecamatan Sikur belum menjamin jumlah produktivitas cabainya menunjukkan hasil yang bagus. Dalam beberapa tahun terakhir produktivitas cabai besar di Kecamatan Sikur mengalami fluktuasi dan penurunan. Hal tersebut mengindikasikan adanya risiko yang dihadapi petani dalam budidaya cabai besar di Kecamatan Sikur.

Menurut Kountur (2008) risiko sangat erat hubungannya dengan ketidakpastian. Hanafi (2009) menjelaskan bahwa ketidakpastian dapat tercermin dari fluktuasi pergerakan yang tinggi, bila semakin tinggi fluktuasi maka semakin besar tingkat ketidakpastiannya. Ketidakpastian atau risiko menyebabkan hasil panen tidak sesuai dengan hasil yang diharapkan bahkan dapat menyebabkan kerugian bagi petani. Faktor-faktor produksi baik faktor eksternal maupun faktor internal akan sangat mempengaruhi dan menentukan hasil produksi cabai besar yang dilakukan petani (Cahyono, 2008). Risiko usahatani hortikultura disebabkan faktor iklim (panas), cuaca (hujan), dan serangan hama, sedangkan risiko harga disebabkan oleh over produksi, Produk hortikultura impor, dan biaya kargo (Tanaya et al, 2021).

Faktor-faktor produksi atau input yang biasanya digunakan dalam budidaya cabai

Putri, S.D.K., Amiruddin, dan Usman, A. 
besar antara lain bibit, pupuk kandang, pupuk kimia, dan zat pengatur tumbuh. Sedangkan faktor eksternal yang mempengaruhi produksi yaitu pengairan dan serangan HPT (Hama dan Penyakit Tanaman). Faktor-faktor tersebut merupakan faktor yang mempengaruhi risiko produksi, ada beberapa faktor yang meningkatkan risiko produksi dan ada yang menurunkan risiko produksi. Selain itu, fluktuasi dan penurunan produktivitas menunjukkan bahwa petani cabai besar di Kecamatan Sikur menghadapi risiko produksi yang diduga disebabkan oleh penggunaan faktor-faktor produksi dan faktor eksternal (non input). Berdasarkan riset terdahulu seperti di daerah Kabupaten Bandung Barat sebagai salah satu sentra produksi cabai nasional, produksi cabai di wilayah tersebut mengalami fluktuasi dan belum mencapai standar optimal yang mengindikasikan adanya risiko produksi (Hadhi, 2017).

Berdasarkan uraian di atas maka penulis merasa penting untuk melakukan penelitian tentang Analisis Risiko Produksi Cabai Besar di Kecamatan Sikur Kabupaten Lombok Timur. Pada penelitian ini dapat dirumuskan beberapa permasalahan yang akan di bahas, antara lain yaitu : (1) Berapa produksi pada usahatani cabai besar di Kecamatan Sikur Kabupaten Lombok Timur?; (2) Bagaimana risiko produksi pada usahatani cabai besar di Kecamatan Sikur Kabupaten Lombok Timur?; (3) Apa saja faktor yang mempengaruhi risiko produksi pada usahatani cabai besar di Kecamatan Sikur Kabupaten Lombok Timur?; (4) Bagaimana Rekomendasi penanganan risiko produksi pada usahatani cabai besar di Kecamatan Sikur Kabupaten Lombok Timur?.

Penelitian ini bertujuan untuk: (1) mengetahui produksi pada usahatani cabai besar di KecamatanSikur Kabupaten Lombok Timur; (2) menganalisis risiko produksi pada usahatani cabai besar di Kecamatan Sikur Kabupaten Lombok Timur; (3) menganalisis faktor-faktor yang mempengaruhi risiko produksi pada usahatani cabai besar di Kecamatan Sikur Kabupaten Lombok Timur; (4) menentukan rekomendasi penanganan risiko produksi pada usahatani cabai besar di Kecamatan Sikur Kabupaten Lombok Timur.

\section{METODE PENELITIAN}

Metode yang digunakan dalam penelitian ini adalah metode deskriptif, yaitu suatu metode dalam meneliti status sekelompok manusia, suatu objek, suatu set kondisi, suatu sistem pemikiran ataupun suatu kelas peristiwa pada masa sekarang. Tujuan dari penelitian deskriptif ini adalah untuk membuat deskripsi, gambaran, atau lukisan secara sistematis, faktual dan akurat mengenai fakta-fakta, sifat-sifat serta hubungan atau fenomena yang diselidiki (Nazir, 2014). Unit analisis pada penelitian ini adalah usahatani cabai besar di Kecamatan Sikur Kabupaten Lombok Timur. Penentuan daerah sampel dilakukan secara Purposive Sampling dengan pertimbangan memilih daerah sampel berdasarkan produktivitas tertinggi, produktivitas sedang, dan produktivitas terendah. Jumlah responden ditentukan secara quota sampling sebanyak 40 orang petani ( $50 \%$ dari jumlah populasi sebanyak 79 orang). Sedangkan penentuan jumlah responden di masing-masing daerah sampel dilakukan secara proportional random sampling.

Jenis data yang digunakan dalam penelitian ini adalah data kualitatif dan data kuantitatif. Sumber data yang digunakan dalam penelitian ini adalah data primer dan sekunder. Variabel-variabel yang diukur dalam penelitian ini yaitu: (1) Luas tanam cabai besar; (2) bibit; (3) pupuk kandang; (4) pupuk kimia; (5) zat pengatur tumbuh; (6) intensitas pengairan; (7) intensitas serangan HPT; dan (8) produksi cabai besar. 
Teknik pengumpulan data yang digunakan dalam penelitian ini adalah teknik survei dan wawancara langsung kepada responden dengan mengajukan beberapa daftar pertanyaan yang telah disusun dan disiapkan sebelumnya.

\section{Analisis Data}

Analisis Produktivitas

1. Menghitung produktivitas cabai besar

Produktivitas $=\frac{Q}{L}$

Keterangan :

$\mathrm{Q} \quad=$ Produksi $(\mathrm{kg})$

$\mathrm{L} \quad=$ Luas Lahan (ha)

Analisis Risiko Produksi

1. Ragam (Variance) dapat dihitung dengan rumus:

$\mathbf{V a}^{2}=\frac{\sum(\mathrm{X} i-\bar{X})^{2}}{n-1}$

Keterangan:

$V a^{2}=$ Variance atau ragam

xi $=$ Produksi per ha $(\mathrm{kg} / \mathrm{ha})$

$\bar{X}=$ Rata-rata produksi per ha $(\mathrm{kg} / \mathrm{ha})$

$\mathrm{n}=$ Jumlah data

2. Simpangan baku (standard deviation) dapat dihitung dengan rumus:

$\mathbf{V a}=\sqrt{\mathrm{Va}^{2}}$

Keterangan :

$\mathrm{V} a$ = Simpangan Baku atau Standard deviation

$V a^{2}=$ Ragam atau Variance

3. Koefisien Variasi (Coefficient Variation)

$\mathrm{KV}=\frac{\mathrm{Va}}{\bar{X}}$

Keterangan :

$\mathrm{KV} \quad=$ Koefisien Variasi

$\mathrm{Va}=$ Standar Deviasi

$\bar{X}=$ Rata-rata produksi per ha $(\mathrm{kg} / \mathrm{ha})$

\section{Analisis Faktor-faktor yang Mempengaruhi Risiko Produksi}

Berdasarkan ISO (2009) ketidakpastian yang merugikan disebut risiko negatif dan ketidakpastian yang menguntungkan disebut risiko positif atau sering disebut dengan opportunity (kesempatan). Oleh karena itu, digunakan dua fungsi variance produktivitas yaitu fungsi variance produktivitas positif dan fungsi variance produktivitas negatif.

Variance Produktivitas :

$\sigma^{2} \mathrm{Y}=(\mathrm{Y}-\hat{\mathrm{Y}})^{2}$

Fungsi Variance Produktivitas positif : 
$\operatorname{Ln} \sigma 2 Y($ positif $)=\theta 0+\theta 1 \operatorname{LnX} 1+\theta 2 \operatorname{LnX} 2+\theta 3 \operatorname{LnX} 3+\theta 4 \operatorname{LnX} 4+\theta 5 \operatorname{LnX} 5+\theta 6 \operatorname{LnX} 6+\varepsilon$

Fungsi Variance Produktivitas negatif :

$\operatorname{Ln} \sigma 2 Y($ negatif $)=\theta 0+\theta 1 \operatorname{LnX} 1+\theta 2 \operatorname{LnX} 2+\theta 3 \operatorname{LnX} 3+\theta 4 \operatorname{LnX} 4+\theta 5 \operatorname{LnX} 5+\theta 6 \operatorname{LnX} 6+\varepsilon$

Keterangan:

$\mathrm{Y}=$ Produktivitas cabai besar aktual $(\mathrm{kg} / \mathrm{ha})$

$\hat{\mathrm{Y}} \quad=$ Rata-rata produktivitas cabai besar $(\mathrm{kg} / \mathrm{ha})$

$\mathrm{X}_{1} \quad=$ Jumlah penggunaan bibit per musim tanam (batang)

$\mathrm{X}_{2} \quad=$ Jumlah penggunaan pupuk kandang per musim tanam $(\mathrm{kg} / \mathrm{ha})$

$\mathrm{X}_{3} \quad=$ Jumlah penggunaan pupuk kimia per musim tanam $(\mathrm{kg} / \mathrm{ha})$

$\mathrm{X}_{4} \quad=$ Jumlah penggunaan zat pengatur tumbuh $(\mathrm{ml} / \mathrm{ha})$

$\mathrm{X}_{5} \quad=$ Intensitas pengairan $(\%)$

$\mathrm{X}_{6} \quad=$ Intensitas serangan OPT $(\%)$

$\sigma^{2} \mathrm{Y}=$ Variance produktivitas cabai besar

$\varepsilon \quad=$ error

$\mathrm{I} \quad=$ Petani responden

$\beta 1, \beta 2, \ldots, \beta 6=$ Koefisien parameter dugaan $X_{1}, X_{2}, \ldots, X_{6}$

$\theta 1, \theta 2, \ldots, \theta 6=$ Koefisien parameter dugaan $\mathrm{X}_{1}, \mathrm{X}_{2}, \ldots, \mathrm{X}_{6}$

\section{Analisis Rekomendasi Penanganan Risiko Produksi}

Rekomendasi penanganan risiko dianalisis dengan menggunakan teknik analisis deskriptif yaitu dengan melihat hasil analisis faktor-faktor yang mempengaruhi risiko produksi pada usaha budidaya cabai besar, sehingga dapat diketahui cara penanganan yang tepat untuk dapat meningkatkan terjadinya risiko produksi positif (opportunity) dan meminimalkan terjadinya risiko produksi negatif yang dihadapi petani cabai besar disesuaikan dengan Standard Operational Procedure (SOP) budidaya cabai besar dari Dinas Pertanian.

\section{HASIL DAN PEMBAHASAN}

\section{Produktivitas Cabai Besar}

Produksi adalah hasil panen cabai besar secara keseluruhan sampai tanaman cabai besar tersebut tidak dapat berproduksi lagi. Produksi cabai besar di Kecamatan Sikur Kabupaten Lombok Timur dapat dilihat pada Tabel 1.

Tabel 1. Produksi Usahatani Cabai Besar di Kec. Sikur Kab. Lombok Timur

\begin{tabular}{cccr}
\hline Produksi $(\mathrm{Kg} / \mathrm{Ha})$ & Musim Kemarau & Musim Hujan & MK + MH \\
\hline Jumlah & 732.426 & 247.145 & 979.570 \\
Rata-rata & 18.311 & 6.179 & 12.245 \\
\hline
\end{tabular}

Sumber: Data primer diolah (2020)

Berdasarkan Tabel 1 rata-rata jumlah produksi cabai besar di Kecamatan Sikur Kabupaten Lombok Timur pada musim kemarau dan musim hujan masing-masing sebesar $18.311 \mathrm{~kg} / \mathrm{ha}$ dan $6.179 \mathrm{~kg} / \mathrm{ha}$. Sedangkan rata-rata produksi cabai besar secara keseluruhan yaitu sebesar $12.245 \mathrm{~kg} / \mathrm{ha}$. Dapat dilihat rata-rata produksi cabai besar yang diperoleh petani pada musim kemarau lebih besar daripada produksi cabai besar pada musim hujan. Hal tersebut disebabkan pada musim kemarau tanaman cabai besar dapat tumbuh dengan baik dibandingkan dengan musim hujan. Pada musim hujan hasil produksi cabai besar yang diperoleh petani lebih sedikit karena menanam 
cabai besar pada musim hujan akan mengalami gangguan yang lebih banyak seperti curah hujan yang terlalu tinggi, serangan hama dan penyakit. Curah hujan yang terlalu tinggi mengakibatkan genangan, sedangkan tanaman cabai besar tidak tahan terhadap genangan karena akan mengakibatkan akar menjadi busuk. Selain itu, pada musim hujan keadaan udara dan tanah lebih lembab sehingga jamur lebih mudah berkembang dan menyerang tanaman cabai besar. Oleh karena itu, musim hujan sering disebut off season untuk menanam cabai besar. Jumlah produksi cabai besar pada musim kemarau dan musim hujan yang diperoleh masing-masing responden mengalami fluktuasi.

\section{Analisis Risiko Produksi Cabai Besar}

Risiko produksi merupakan risiko yang muncul akibat ketidakpastian jumlah hasil panen yang diperoleh dari suatu usahatani. Risiko dalam penelitian ini termasuk risiko spekulatif (speculative risk). Menurut Hanafi (2009) risiko spekulatif (speculative risk) adalah risiko yang berkaitan dengan terjadinya dua kemungkinan yaitu kemungkinan mengalami kerugian atau memperoleh keuntungan. Besarnya risiko produksi usahatani cabai besar pada musim kemarau dan musim hujan di Kecamatan Sikur Kabupaten Lombok Timur dapat dilihat pada Tabel 2.

Tabel 2. Risiko Produksi Usahatani Cabai Besar di Kec. Sikur Kab. Lombok Timur

\begin{tabular}{clr}
\hline No & \multicolumn{1}{c}{ Keterangan } & Nilai per Ha \\
\hline 1. & Produksi rata-rata & 12.245 \\
2. & Variance & 38.250 .097 \\
3. & Simpangan baku & 6.185 \\
4. & Koefisien Variasi (KV) & 0,51 \\
\hline
\end{tabular}

Sumber: Data primer diolah (2020)

Produktivitas rata-rata atau produktivitas harapan merupakan produktivitas yang diharapkan oleh petani cabai besar di Kecamatan Sikur Kabupaten Lombok Timur yaitu sebesar $12.245 \mathrm{~kg} / \mathrm{ha}$. Produktivitas harapan petani sama dengan produktivitas rata-rata dari keseluruhan petani responden. Hal tersebut dikarenakan kesamaan peluang dari masing-masing petani responden untuk menghasilkan produktivitas yang diharapkan.

Nilai variance berbanding lurus dengan nilai penyimpangan dan risiko yang dihadapi petani. Semakin besar nilai variance, maka semakin besar penyimpangannya dan semakin besar tingkat risiko yang dihadapi petani dalam menjalankan usahatani cabai besar.

Nilai koefisien variasi (Coefficient Variation) berbanding lurus dengan risiko produksi yang dihadapi petani. Besar kecilnya nilai koefisien variasi (Coefficient Variation) tergantung dari besar kecilnya fluktuasi produksi dari masing-masing petani responden. Semakin besar fluktuasi produksi cabai besar, maka semakin besar nilai koefisien variasi (Coefficient Variation) sehingga ketidakpastian atau risiko produksi juga semakin besar. Begitupun sebaliknya, semakin kecil fluktuasi produksi cabai besar, maka semakin kecil nilai koefisien variasi (Coefficient Variation) sehingga ketidakpastian atau risiko produksi juga semakin kecil.

Berdasarkan Tabel 2 dapat dilihat bahwa risiko produksi pada usahatani cabai besar tergolong tinggi yang dilihat dari nilai koefisien variasi (Coefficient Variation) > 0,5 yaitu sebesar 0,51 . Artinya, untuk setiap $1 \mathrm{~kg}$ produksi yang diharapkan, maka petani cabai besar akan menghadapi penyimpangan (penyimpangan positif atau negatif) sebesar $0,51 \mathrm{~kg}$. Besarnya risiko tersebut diakibatkan karena besarnya fluktuasi produktivitas cabai besar. Hal tersebut disebabkan oleh kondisi cuaca yang 
tidak menentu dan tidak dapat diprediksi, tingginya intensitas serangan hama dan penyakit, serta penggunaan input produksi yang tidak sesuai dengan standar penggunaannya.

Analisis Faktor-faktor yang Mempengaruhi Risiko Produksi

Analisis Faktor-faktor yang Mempengaruhi Risiko Produksi Positif (Opportunity)

Tabel 3.Hasil Analisis Regresi Faktor-faktor yang Mempengaruhi Risiko Produksi Positif(Opportunity)

\begin{tabular}{|c|c|c|c|c|c|c|}
\hline \multicolumn{4}{|c|}{ Coefficients $^{\mathrm{a}}$} & & & \\
\hline \multirow{2}{*}{\multicolumn{2}{|c|}{ Model }} & \multicolumn{2}{|c|}{$\begin{array}{c}\text { Unstandardized } \\
\text { Coefficients } \\
\end{array}$} & \multirow{2}{*}{$\begin{array}{l}\text { Standardized } \\
\text { Coefficients } \\
\text { Beta }\end{array}$} & \multirow[t]{2}{*}{$\mathrm{t}$} & \multirow[t]{2}{*}{ Sig. } \\
\hline & & $\mathrm{B}$ & Std. Error & & & \\
\hline \multirow[t]{7}{*}{1} & (Constant) & 106,363 &, 043 & & 5,968 & ,000 \\
\hline & Bibit & $-2,035$ & ,007 &,- 012 & $-3,080$ &, 014 \\
\hline & Pupuk Kandang & 3,485 & ,038 & , 124 & 4,690 & ,001 \\
\hline & Pupuk Kimia & $-4,196$ & ,012 &,- 195 & $-4,291$ &, 001 \\
\hline & ZPT & 1,009 & ,017 - - - & 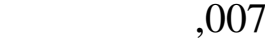 & 2,971 & , 028 \\
\hline & Intens. Pengairan & 2,044 &, 020 & 017 & 4,022 &, 002 \\
\hline & $\begin{array}{l}\text { Intens. Serangan } \\
\text { HPT }\end{array}$ & $-78,588$ & ,028 & $-1,208$ & $-5,663$ & 000 \\
\hline
\end{tabular}

a. Dependent Variable: Variance

Sumber: Data primer diolah (2020)

Berdasarkan hasil analisis semua variabel independen (bibit, pupuk kandang, pupuk kimia, zat pengatur tumbuh, intensitas pengairan, dan intensitas serangan HPT) berpengaruh nyata atau signifikan terhadap varian produktivitas cabai besar di Kecamatan Sikur Kabupaten Lombok Timur. Berikut ini akan dijelaskan bagaimana hubungan atau pengaruh variabel independen terhadap variabel dependen.

1. Pengaruh Jumlah Bibit terhadap Variance Produktivitas Positif dan Risiko Produksi Positif(Opportunity)

Hasil pendugaan fungsi variance produktivitas positif cabai besar menunjukkan bahwa variabel bibit mempunyai tanda negatif dan signifikan pada taraf nyata 5 persen. Oleh karena itu, variabel bibit merupakan faktor yang mengurangi risiko produksi positif atau opportunity (opportunity reducing factor). Nilai koefisien parameter bibit yaitu -2,035. Artinya, setiap penambahan penggunaan bibit sebesar 1 batang maka akan mengurangi variance produktivitas positif sebesar $2,035 \mathrm{~kg}$ atau opportunity sebesar 0,00011 (dalam keadaan variabel lain dianggap konstan).

2. Pengaruh Jumlah Pupuk Kandang terhadap Variance Produktivitas Positif dan Risiko Produksi Positif (Opportunity)

Hasil pendugaan fungsi variance produktivitas cabai besar menunjukkan bahwa variabel pupuk kandang mempunyai tanda positif dan signifikan pada taraf nyata 5 persen. Oleh karena itu, variabel pupuk kandang merupakan faktor yang meningkatkan risiko produksi positif atau opportunity (opportunity inducing factor). Nilai koefisien parameter pupuk kandang yaitu 3,485. Artinya, setiap penambahan penggunaan pupuk kandang sebesar $1 \mathrm{~kg}$ maka akan meningkatkan variance produktivitas positif sebesar 3,485 $\mathrm{kg}$ atau opportunity sebesar 0,00015 (dalam keadaan variabel lain dianggap konstan).

3. Pengaruh Jumlah Pupuk Kimia terhadap Variance Produktivitas Positif dan Risiko Produksi Positif (Opportunity) 
Hasil pendugaan fungsi variance produktivitas cabai besar menunjukkan bahwa variabel pupuk kimia mempunyai tanda negatif dan signifikan pada taraf nyata 5 persen. Oleh karena itu, variabel pupuk kimia merupakan faktor yang mengurangi risiko produksi positif atau opportunity (opportunity reducing factor). Nilai koefisien parameter pupuk kimia yaitu -4,196. Artinya, setiap penambahan penggunaan pupuk kimia sebesar $1 \mathrm{~kg}$ maka akan mengurangi variance produktivitas positif sebesar $4,196 \mathrm{~kg}$ atau risiko produksi sebesar 0,00016 (dalam keadaan variabel lain dianggap konstan).

4. Pengaruh Jumlah zat pengatur tumbuh terhadap Variance Produktivitas Positif dan Risiko Produksi Positif (Opportunity)

Hasil pendugaan fungsi variance produktivitas cabai besar menunjukkan bahwa variabel zat pengatur tumbuh mempunyai tanda positif dan signifikan pada taraf nyata 5 persen. Oleh karena itu, variabel zat pengatur tumbuh merupakan faktor yang meningkatkan risiko produksi positif atau opportunity (opportunity inducing factor). Nilai koefisien parameter zat pengatur tumbuh yaitu 1,009. Artinya, setiap penambahan penggunaan zat pengatur tumbuh sebesar $1 \mathrm{ml}$ maka akan meningkatkan variance produktivitas positif sebesar $1,009 \mathrm{~kg}$ atau opportunity sebesar 0,00008 (dalam keadaan variabel lain dianggap konstan).

5. Pengaruh Jumlah Intensitas Pengairan terhadap Variance Produktivitas Positif dan Risiko Produksi Positif (Opportunity)

Hasil pendugaan fungsi variance produktivitas cabai besar menunjukkan bahwa variabel intensitas pengairan mempunyai tanda positif dan signifikan pada taraf nyata 5 persen. Oleh karena itu, variabel intensitas pengairan merupakan faktor yang meningkatkan risiko produksi positif atau opportunity (opportunity inducing factor). Nilai koefisien parameter intensitas pengairan yaitu 2,004. Artinya, setiap peningkatan intensitas pengairan sebesar 1 persen maka akan meningkatkan variance produktivitas positif sebesar 2,044 $\mathrm{kg}$ atau opportunity sebesar 0,00012 (dalam keadaan variabel lain dianggap konstan).

6. Pengaruh Jumlah Intensitas Serangan HPT terhadap Variance Produktivitas Positif dan RisikoProduksi Positif (Opportunity)

Hasil pendugaan fungsi variance produktivitas cabai besar menunjukkan bahwa variabel intensitas serangan HPT mempunyai tanda negatif dan signifikan pada taraf nyata 5 persen. Oleh karena itu, variabel intensitas serangan HPT merupakan faktor yang mengurangi risiko produksi positif atau opportunity (opportunity reducing factor). Nilai koefisien parameter intensitas serangan HPT yaitu - 78,588. Artinya, setiap peningkatan intensitas serangan HPT sebesar 1 persen maka akan mengurangi variance produktivitas positif sebesar $78,588 \mathrm{~kg}$ atau opportunity sebesar 0,00071 (dalam keadaan variabel lain dianggap konstan).

Analisis Faktor-faktor yang Mempengaruhi Risiko Produksi Negatif

Tabel 4. Hasil Analisis Regresi Faktor-faktor yang Mempengaruhi Risiko Produksi Negatif

\begin{tabular}{|c|c|c|c|c|c|}
\hline Coe & ientsa & & & & \\
\hline \multirow[t]{3}{*}{ Model } & \multirow{2}{*}{\multicolumn{2}{|c|}{$\begin{array}{l}\text { Unstandardized } \\
\text { Coefficients }\end{array}$}} & Standardized & \multirow[t]{3}{*}{$\mathrm{t}$} & \multirow[t]{3}{*}{ Sig. } \\
\hline & & & Coefficients & & \\
\hline & $\mathrm{B}$ & Std. Error & Beta & & \\
\hline \multirow{3}{*}{$\begin{array}{l}\text { (Constant) } \\
\text { Bibit } \\
\text { Pupuk Kandang }\end{array}$} & 172,775 &, 045 & & 5,798 & ,000 \\
\hline & $-4,727$ & 012 &,- 309 & $-3,657$ & 001 \\
\hline & $-9,259$ & ,019 & $-1,208$ & $-5,106$ &, 000 \\
\hline
\end{tabular}

Putri, S.D.K., Amiruddin, dan Usman, A. 


\begin{tabular}{|c|c|c|c|c|c|}
\hline \multicolumn{3}{|c|}{ Coefficientsa } & & & \\
\hline \multirow[t]{2}{*}{ Model } & \multicolumn{2}{|c|}{$\begin{array}{l}\text { Unstandardized } \\
\text { Coefficients }\end{array}$} & \multirow{2}{*}{$\begin{array}{l}\text { Standardized } \\
\text { Coefficients } \\
\text { Beta }\end{array}$} & \multirow[t]{2}{*}{$\mathrm{t}$} & \multirow[t]{2}{*}{ Sig. } \\
\hline & $\mathrm{B}$ & Std. Error & & & \\
\hline Pupuk Kimia & 11,781 & ,027 & ,009 & 4,175 & ,000 \\
\hline ZPT & $-2,270$ & ,003 &,- 007 & $-3,256$ & ,003 \\
\hline Intens. Pengairan & 1,991 & ,020 &, 001 & 2,295 & ,039 \\
\hline $\begin{array}{l}\text { Intens. Serangan } \\
\text { HPT }\end{array}$ & 140,584 & ,038 & 1,893 & 5,310 &, 000 \\
\hline
\end{tabular}

a. Dependent Variable: Variance

Sumber: Data primer diolah (2020)

1. Pengaruh Jumlah Bibit terhadap Variance Produktivitas Negatif dan Risiko Produksi

Hasil pendugaan fungsi variance produktivitas Negatif cabai besar menunjukkan bahwa variabel bibit mempunyai tanda negatif dan signifikan pada taraf nyata 5 persen. Oleh karena itu, variabel bibit merupakan faktor yang mengurangi risiko produksi (risk reducing factor). Nilai koefisien parameter bibit yaitu $-4,727$. Artinya, setiap penambahan penggunaan bibit sebesar 1 batang maka akan mengurangi variance produktivitas negatif sebesar $4,727 \mathrm{~kg}$ atau risiko produksi sebesar 0,00017 (dalam keadaan variabel lain dianggap konstan).

2. Pengaruh Jumlah Pupuk Kandang terhadap Variance Produktivitas Negatif dan Risiko Produksi

Hasil pendugaan fungsi variance produktivitas negatif cabai besar menunjukkan bahwa variabel pupuk kandang mempunyai tanda negatif dan signifikan pada taraf nyata 5 persen. Oleh karena itu, variabel pupuk kandang merupakan faktor yang mengurangi risiko produksi (risk reducing factor). Nilai koefisien parameter pupuk kandang yaitu -9,259. Artinya, setiap penambahan penggunaan pupuk kimia sebesar 1 $\mathrm{kg}$ maka akan mengurangi variance produktivitas negatif sebesar 9,259 kg atau risiko produksi sebesar 0,00074 (dalam keadaan variabel lain dianggap konstan).

3. Pengaruh Jumlah Pupuk Kimia terhadap Variance Produktivitas Negatif dan Risiko Produksi

Hasil pendugaan fungsi variance produktivitas negatif cabai besar menunjukkan bahwa variabel pupuk kimia mempunyai tanda positif dan signifikan pada taraf nyata 5 persen. Oleh karena itu, variabel pupuk kimia merupakan faktor yang meningkatkan risiko produksi (risk inducing factor). Nilai koefisien parameter pupuk kimia yaitu 11,781. Artinya, setiap penambahan penggunaan pupuk kimia sebesar $1 \mathrm{~kg}$ maka akan meningkatkan variance produktivitas negatif sebesar $11,781 \mathrm{~kg}$ atau risiko produksi sebesar 0,00027 (dalam keadaan variabel lain dianggap konstan).

4. Pengaruh Jumlah zat pengatur tumbuh terhadap Variance Produktivitas Negatif dan Risiko Produksi

Hasil pendugaan fungsi variance produktivitas negatif cabai besar menunjukkan bahwa variabel zat pengatur tumbuh mempunyai tanda negatif dan signifikan pada taraf nyata 5 persen. Oleh karena itu, variabel zat pengatur tumbuh merupakan faktor yang mengurangi risiko produksi (risk reducing factor). Nilai koefisien parameter zat pengatur tumbuh yaitu -2,270. Artinya, setiap penambahan penggunaan zat pengatur tumbuh sebesar 1 liter maka akan mengurangi variance produktivitas negatif sebesar $2,270 \mathrm{~kg}$ atau risiko produksi sebesar 0,00012 (dalam keadaan variabel lain dianggap konstan).

5. Pengaruh Jumlah Intensitas Pengairan terhadap Variance Produktivitas Negatif dan Risiko Produksi 
Hasil pendugaan fungsi variance produktivitas negatif cabai besar menunjukkan bahwa variabel

intensitas pengairan mempunyai tanda positif dan signifikan pada taraf nyata 5 persen. Oleh karena itu, variabel intensitas pengairan merupakan faktor yang meningkatkan risiko produksi (risk inducing factor). Nilai koefisien parameter intensitas pengairan yaitu 1,991. Artinya, setiap peningkatan intensitas pengairan sebesar 1 persen maka akan meningkatkan variance produktivitas negatif sebesar $1,991 \mathrm{~kg}$ atau risiko produksi sebesar 0,00011 (dalam keadaan variabel lain dianggap konstan).

6. Pengaruh Jumlah Intensitas Serangan HPT terhadap Variance Produktivitas Negatif dan Risiko Produksi

Hasil pendugaan fungsi variance produktivitas negatif cabai besar menunjukkan bahwa variabel intensitas serangan HPT mempunyai tanda positif dan signifikan pada taraf nyata 5 persen. Oleh karena itu, variabel intensitas serangan HPT merupakan faktor yang meningkatkan risiko produksi (risk inducing factor). Nilai koefisien parameter intensitas serangan HPT yaitu 140,584. Artinya, setiap peningkatan intensitas serangan HPT sebesar 1 persen maka akan meningkatkan variance produktivitas negatif sebesar 140,584 $\mathrm{kg}$ atau risiko produksi sebesar 0,00095 (dalam keadaan variabel lain dianggap konstan).

\section{Rekomendasi Penanganan Risiko Produksi Rekomendasi Penanganan Risiko Produksi Positif(Opportunity)}

1. Bibit

Bibit yang digunakan petani responden pada musim kemarau telah melebihi aturan dalam Standar Operasional Pertanian (SOP) budidaya cabai besar. Dalam Standar Operasional Pertanian (SOP) budidaya cabai besar penggunaan bibit cabai besar berkisar antara 23.000 sampai 26.000 batang/ha sesuai dengan jarak tanam yang digunakan, sedangkan rata-rata jumlah bibit yang digunakan petani responden sebanyak 27.138 batang/ha. Oleh karena itu, petani direkomendasikan untuk mengurangi jumlah bibit yang digunakan hingga batas yang telah ditentukan.

2. Pupuk Kandang

Pupuk kandang yang digunakan petani responden belum memenuhi aturan dalam Standar Operasional Pertanian (SOP) budidaya cabai besar. Dalam Standar Operasional Pertanian (SOP) budidaya cabai besar penggunaan pupuk kandang yang berasal dari kotoran sapi sebanyak $5.000 \mathrm{~kg} / \mathrm{ha}$, sedangkan rata-rata jumlah pupuk kandang yang digunakan petani responden sebanyak $4.059 \mathrm{~kg} / \mathrm{ha}$. Oleh karena itu, petani direkomendasikan untuk menambah jumlah pupuk kandang yang digunakan hingga batas yang telah ditentukan. Pemanfaatan pupuk kandang akan mengurangi biaya kegiatan usahatani yang pada akhirnya dapat meningkatkan pendapatan petani (Suparyana, 2020)

3. Pupuk Kimia

Pupuk kimia yang digunakan petani responden melebihi aturan dalam Standar Operasional Pertanian (SOP) budidaya cabai besar. Dalam Standar Operasional Pertanian (SOP) budidaya cabai besar penggunaan pupuk kimia sebanyak $2.100 \mathrm{~kg} / \mathrm{ha}$ den gan rincian yaitu urea $250 \mathrm{~kg} / \mathrm{ha}$, NPK $350 \mathrm{~kg} / \mathrm{ha}$, phonska plus $800 \mathrm{~kg} / \mathrm{ha}, \mathrm{ZA}$ $400 \mathrm{~kg} / \mathrm{ha}$, dan SP36 $300 \mathrm{~kg} / \mathrm{ha}$. Sedangkan rata-rata jumlah pupuk kimia yang digunakan petani responden sebanyak $2.632 \mathrm{~kg} / \mathrm{ha}$ dengan rincian yaitu urea 319 kg/ha, NPK 467 kg/ha, phonska plus $945 \mathrm{~kg} / \mathrm{ha}$, ZA $479 \mathrm{~kg} / \mathrm{ha}$, dan SP36 $422 \mathrm{~kg} / \mathrm{ha}$. Oleh karena itu, petani direkomendasikan untuk mengurangi jumlah pupuk kimia yang digunakan hingga batas yang telah ditentukan, karena penggunaan pupuk kimia 
akan memberikan manfaat yang maksimal hanya jika digunakan dengan dosis yang tepat. Selain itu, rata-rata petani responden mencampur beberapa jenis pupuk kimia dalam melakukan pemupukan susulan. Oleh karena itu, petani direkomendasikan untuk tidakmencampur berbagai jenis pupuk kimia karena antar senyawa kimia dapat bereaksi yang justru memberikan dampak yang buruk bagi tanaman.

4. Zat Pengatur Tumbuh

Zat pengatur tumbuh yang digunakan petani responden belum memenuhi aturan dalam Standar Operasional Pertanian (SOP) budidaya cabai besar. Dalam Standar Operasional Pertanian (SOP) penggunaan zat pengatur tumbuh sebanyak $1.750 \mathrm{ml} / \mathrm{ha}$ dengan rincian atonik $400 \mathrm{ml} / \mathrm{ha}$, giberelin 400 liter/ha, bigest $250 \mathrm{ml} / \mathrm{ha}$, auksin 400 $\mathrm{ml} / \mathrm{ha}$, dan sitokinin $300 \mathrm{ml}$. Sedangkan rata-rata jumlah zat pengatur tumbuh yang digunakan petani responden sebanyak $1.299 \mathrm{ml} / \mathrm{ha}$ dengan rincian yaitu atonik 347 $\mathrm{ml} / \mathrm{ha}$, giberelin $268 \mathrm{ml} / \mathrm{ha}$, bigest $229 \mathrm{ml} / \mathrm{ha}$, auksin $270 \mathrm{ml} / \mathrm{ha}$, dan sitokinin 185 $\mathrm{ml} / \mathrm{ha}$. Oleh karena itu, petani direkomendasikan untuk menambah jumlah zat pengatur tumbuh yang digunakan hingga batas yang telah ditentukan.

5. Intensitas Pengairan

Intensitas pengairan yang dilakukan pada musim panas terlalu rendah yaitu hanya 43 persen, sehingga menyebabkan tanaman cabai kekurangan air. Hal tersebut mengakibatkan tanaman cabai menjadi layu menguning dan lama-kelamaan akan mati. Selain itu, jika tanaman cabai besar yang kekurangan air berbunga maka bunganya akan mudah rontok dan buah yang dihasilkan memiliki kualitas yang rendah. Oleh karena itu, petani direkomendasikan untuk meningkatkan intensitas pengairan, meskipun harus mengeluarkan biaya yang lebih mahal.

6. Intensitas Serangan Hama dan Penyakit

Intensitas serangan hama dan penyakit tidak terlalu tinggi pada musim kemarau jika dibandingkan intensitas serangan HPT pada musim hujan. Intensitas serangan HPT pada musim kemarau yaitu sebesar 16,47 persen. Artinya, luas tanam cabai besar yang terserang hama dan penyakit kurang dari 50 persen. Hal tersebut merupakan salah satu faktor yang dapat mempengaruhi produktivitas cabai besar pada musim kemarau. Oleh karena itu, petani direkomendasikan untuk melakukan pengendalian hama dan penyakit baik secara mekanis maupun kimia yang sesuai dengan Standar Operasional Pertanian (SOP) budidaya cabai besar.

Hama dan penyakit tanaman yang menyerang tanaman cabai pada musim kemarau dalam penelitian ini yaitu thrips dan kutu kebul. Setiap jenis hama dan penyakit memiliki pengendalian yang berbeda-beda. Secara mekanis pengendalian untuk thrips dan kutu kebul yaitu dengan penggunaan perangkap likat. Sedangkan, secara kimiawi yaitu dengan menggunakan pestisida. Insektisida untuk mengatasi hama thrips salah satunya adalah besvidor 25 WP yang mengandung bahan aktif imidakloprid. Sedangkan insektisida untuk mengatasi kutu kebul salah satunya adalah Actara 25 WG yang mengandung bahan aktif tiametoksam. Namun penggunaan pestisida harus sesuai dengan dosis yang telah ditentukan. Jika tidak, maka penggunaan pestisida tidak efektif dan disisi lain biaya mengalami pembengkakan.

\section{Rekomendasi Penanganan Risiko Produksi Negatif}

1. Bibit

Bibit yang digunakan petani responden pada musim hujan belum memenuhi aturan dalam Standar Operasional Pertanian (SOP) budidaya cabai besar. Dalam Standar Operasional Pertanian (SOP) budidaya cabai besar penggunaan bibit cabai besar berkisar antara 23.000 sampai 26.000 batang/ha sesuai dengan jarak tanam yang 
digunakan, sedangkan rata-rata jumlah bibit yang digunakan petani responden sebanyak 20.698 batang/ha. Oleh karena itu, petani direkomendasikan untuk menambah jumlah bibit yang digunakan hingga batas yang telah ditentukan. Selain itu, pada musim hujan petani responden direkomendasikan untuk menggunakan bibit yang lebih tahan terhadap serangan hama dan penyangit, karena pada msuim hujan tanaman cabai besar lebih rentan terkena serangan hama dan penyakit dibandingkan musim kemarau.

2. Pupuk Kandang

Pupuk kandang yang digunakan petani responden belum memenuhi aturan dalam

Standar Operasional Pertanian (SOP) budidaya cabai besar. Dalam Standar Operasional Pertanian (SOP) budidaya cabai besar penggunaan pupuk kandang yang berasal dari kotoran sapi sebanyak $5.000 \mathrm{~kg} / \mathrm{ha}$, sedangkan rata-rata jumlah pupuk kandang yang digunakan petani responden sebanyak $3.463 \mathrm{~kg} / \mathrm{ha}$. Oleh karena itu, petani direkomendasikan untuk menambah jumlah pupuk kandang yang digunakan hingga batas yang telah ditentukan.

3. Pupuk Kimia

Pupuk kimia yang digunakan petani responden melebihi aturan dalam Standar Operasional Pertanian (SOP) budidaya cabai besar. Dalam Standar Operasional Pertanian (SOP) penggunaan pupuk kimia sebanyak $2.100 \mathrm{~kg} / \mathrm{ha}$ dengan rincian yaitu urea $250 \mathrm{~kg} / \mathrm{ha}$, NPK $350 \mathrm{~kg} / \mathrm{ha}$, phonska plus $800 \mathrm{~kg} / \mathrm{ha}$, ZA $400 \mathrm{~kg} / \mathrm{ha}$, dan SP36 $300 \mathrm{~kg} / \mathrm{ha}$.Sedangkan rata-rata jumlah pupuk kimia yang digunakan petani responden sebanyak $2.408 \mathrm{~kg} / \mathrm{ha}$ dengan rincian yaitu urea $264 \mathrm{~kg} / \mathrm{ha}$, NPK $375 \mathrm{~kg} / \mathrm{ha}$, phonska plus $910 \mathrm{~kg} / \mathrm{ha}$, ZA $497 \mathrm{~kg} / \mathrm{ha}$, dan SP36 $362 \mathrm{~kg} / \mathrm{ha}$. Oleh karena itu, petani direkomendasikan untuk mengurangi jumlah pupuk kimia yang digunakan hingga batas yang telah ditentukan, karena penggunaan pupuk kimia akan memberikan manfaat yang maksimal hanya jika digunakan dengan dosis yang tepat. Selain itu, rata-rata petani responden mencampur beberapa jenis pupuk kimia dalam melakukan pemupukan susulan. Oleh karena itu, petani direkomendasikan untuk tidak mencampur berbagai jenis pupuk kimia karena antar senyawa kimia dapat bereaksi yang justru memberikan dampak yang buruk bagi tanaman.

4. Zat Pengatur Tumbuh

Zat pengatur tumbuh yang digunakan petani responden belum memenuhi aturan dalam Standar Operasional Pertanian (SOP) budidaya cabai besar. Dalam Standar Operasional Pertanian (SOP) penggunaan zat pengatur tumbuh sebanyak $1.750 \mathrm{ml} / \mathrm{ha}$ dengan rincian atonik $400 \mathrm{ml} / \mathrm{ha}$, giberelin 400 liter/ha, bigest $250 \mathrm{ml} / \mathrm{ha}$, auksin 400 $\mathrm{ml} / \mathrm{ha}$, dan sitokinin $300 \mathrm{ml}$. Sedangkan rata-rata jumlah zat pengatur tumbuh yang digunakan petani responden sebanyak $907 \mathrm{ml} / \mathrm{ha}$ dengan rincian yaitu atonik 306 $\mathrm{ml} /$ ha, giberelin $196 \mathrm{ml} / \mathrm{ha}$, bigest $118 \mathrm{ml} / \mathrm{ha}$, auksin $187 \mathrm{ml} / \mathrm{ha}$, dan sitokinin 100 $\mathrm{ml} / \mathrm{ha}$. Oleh karena itu, petani direkomendasikan untuk menambah jumlah zat pengatur tumbuh yang digunakan hingga batas yang telah ditentukan.

5. Intensitas Pengairan

Intensitas pengairan yang dilakukan pada musim hujan terlalu tinggi yaitu sebesar 93,33 persen ditambah lagi dengan curah hujan yang tinggi, meskipun terkadang cuaca tidak menentu sehingga air yang diterima tanaman cabai besar berlebihan yang menyebabkan tanaman layu meskipun tampak masih hijau dan penyakit mudah berkembang karena kelembaban tanah yang tinggi. Oleh karena itu, petani direkomendasikan untuk mengurangi intensitas pengairan dan melakukan drainase yang baik dengan membuat saluran-saluran air di sela-sela bedengan, serta membuat bedengan yang lebih tinggi untuk menghindari genangan.

Putri, S.D.K., Amiruddin, dan Usman, A. 
6. Intensitas Serangan Hama dan Penyakit

Intensitas serangan hama dan penyakit terlalu tinggi pada musim hujan yaitu sebesar 51,50 persen. Artinya, luas tanam cabai besar yang terserang hama dan penyakit lebih dari 50 persen. Hal tersebut merupakan salah satu faktor yang menyebabkan produksi pada musim hujan di bawah rata-rata. Oleh karena itu, petani direkomendasikan untuk melakukan pengendalian hama dan penyakit baik secara mekanis maupun kimia yang sesuai dengan Standar Operasional Pertanian (SOP) budidaya cabai besar.

Hama dan penyakit tanaman yang menyerang tanaman cabai besar pada musim hujan dalam penelitian ini yaitu busuk buah antraknosa, lalat buah, layu bakteri, dan layu fusarium. Setiap jenis hama dan penyakit memiliki pengendalian yang berbedabeda. Secara mekanis pengendalian untuk busuk buah antraknosa, layu bakteri, dan layu fusarium yaitu dengan melakukan pergiliran tanaman dengan tanaman bukan inang dan melakukan perbaikan drainase tanah untuk menghindari genangan dan kelembaban tanah yang cukup tinggi karena dalam keadaan kelembaban tanah yang terlalu tinggi membuat jamur dan bakteri lebih mudah berkembang. Sedangkan pengendalian secara mekanis untuk lalat buah yaitu dengan menggunakan perangkap atraktan (pemikat) lalat buah. Sedangkan secara kimiawi yaitu dengan menggunakan pestisida.

Fungisida untuk mengatasi busuk buah antraknosa salah satunya adalah antracol 70 WP yang mengandung bahan aktif propinep 70 persen, sedangkan untuk mengatasi layu bakteri salah satunya adalah anaconda 50 WP yang mengandung bahan aktif benomil. Bakterisida untuk mengatasi layu bakteri salah satunya adalah agrept $20 \mathrm{WP}$ yang mengandung bahan aktif streptomisin sulfat. Pengendalian lalat buah dengan insektisida berbahan aktif spinosad bisa membunuh lalat buah. Pestisida sebagai umpan dengan bahan aktif spinosad sangat digemari lalat buah baik jantan maupun betina. Namun sayangnya penyemprotan dengan insektisida sering menyebabkan pemborosan karena banyak yang tidak tepat sasaran, mengingat sifat lalat buah yang selalu bergerak.

\section{KESIMPULAN DAN SARAN}

\section{Kesimpulan}

Berdasarkan hasil penelitian dan analisis yang telah dilakukan, maka dapat ditarik kesimpulan sebagai berikut:

1. Rata-rata produksi cabai besar di Kecamatan Sikur Kabupaten Lombok Timur adalah sebesar $12.245 \mathrm{~kg} / \mathrm{ha}$.

2. Risiko produksi pada usahatani cabai besar di Kecamatan Sikur Kabupaten Lombok Timur tergolong tinggi dengan nilai koefisien variasi (KV) sebesar 0,51.

3. Faktor-faktor yang secara nyata dapat meningkatkan risiko produksi positif (opportunity) pada usahatani cabai besar (opportunity inducing factor) yaitu pupuk kandang, zat pengatur tumbuh, dan intensitas pengairan. Sedangkan bibit, pupuk kimia, dan intensitas serangan HPT merupakan faktor yang secara nyata dapat menurunkan risiko produksi positif (opportunity) pada usahatani cabai besar (opportunity reducing factor). Faktor-faktor yang secara nyata dapat meningkatkan risiko produksi negatif pada usahatani cabai besar (risk inducing factor).yaitu pupuk kimia, intensitas pengairan, dan intensitas serangan HPT. Sedangkan bibit, pupuk kandang, dan zat pengatur tumbuh merupakan faktoryang secara nyata dapat menurunkan risiko produksi negatif pada usahatani cabai besar 
(risk reducing factor) di Kecamatan Sikur Kabupaten Lombok Timur.

4. Rekomendasi penanganan risiko produksi untuk meningkatkan risiko produksi positif (opportunity) yaitu dengan mengurangi jumlah penggunaan bibit cabai besar, meningkatkan jumlah penggunaan pupuk kandang, mengurangi jumlah penggunaan pupuk kimia, meningkatkan jumlah penggunaan zat pengatur tumbuh, meningkatkan intensitas pengairan, dan melakukan pengendalian HPT baik secara mekanis maupun kimiawi untuk mengurangi intensitas serangan HPT. Sedangkan rekomendasi penanganan risiko produksi untuk mengurangi risiko produksi negatif yaitu dengan meningkatkan jumlah penggunaan bibit cabai besar, meningkatkan jumlah penggunaan pupuk kandang, mengurangi jumlah penggunaan pupuk kimia, meningkatkan jumlah penggunaan zat pengatur tumbuh, mengurangi intensitas pengairan, dan melakukan pengendelaian HPT baik secara mekanis maupun kimiawi untuk mengurangi intensitas serangan HPT.

\section{Saran}

1. Diharapkan petani cabai besar di Kecamatan Sikur Kabupaten Lombok Timur dapat lebih memperhatikan penggunaan faktor produksi yang berpengaruh terhadap risiko produksi dan disesuaikan dengan standar penggunaan dalam usahatani cabai besar.

2. Diharapkan petani cabai besar dapat bergabung dengan kelompok tani untuk mempermudah dalam mendapatkan informasi yang berkaitan dengan usahatani cabai besar seperti kegiatan pelatihan yang diadakan oleh penyuluhan dari dinas terkait melalui kelompok tani, sehingga risiko produksi negatif dapat diminimalisir dan opportunity dapat ditingkatkan.

3. Diharapkan pemerintah atau dinas terkait dapat melakukan penyuluhan dan pelatihan kepada petani yang berkaitan dengan usahatani cabai besar, terutama penggunaan faktor produksi secara tepat dan pengendalian HPT, sehingga produktivitas cabai besar dapat meningkat .

\section{DAFTAR PUSTAKA}

Badan Pusat Statistik. (2019). Analisis Komoditas Ekspor-Impor Sektor Pertanian. BPS Indonesia: Jakarta.

Badan Pusat Statistik. (2019). KabupatenLombok Timur dalam Angka. BPS Provinsi NTB: Mataram.

Cahyono, B. (2008). Cabai Besar (Usahatani dan Penanganan Pasca panen). Kanisius: Yogyakarta.

Direktorat Jenderal Hortikultura. (2010). Standar Operasional Operasional Prosedur (SOP) Cabai Merah. Ditjen Hortikultura. Kementrian Pertanian: Jakarta.

Hanafi, M. M. (2009). Manajemen Risiko Edisi Kedua. Unit Penerbit dan Percetakan Sekolah Tinggi IlmuManajemen YKPN:Yogyakarta.

Hadhi, R. T. (2017). Analisis Faktor-Faktor yang Memengaruhi Risiko Produksi Cabai Paprika di Desa Pasirlangu Kecamatan Cisarua Kabupaten Bandung Barat.

International Standard. (2009). Risk Management - principles and guidelines ISO 31000:2009. ISOcopyright office. Geneva.

Irsan, Z. T. (2010). Analisis Komparatif Usahatani Tomat Buah Organik dan Anorganik di Kabupaten Banggal. E-Jurnal Agribisnis. 6(3), 19-21.

Kountur, R. (2008). Manajemen Risiko Operasional Perusahaan. Pendidikan 
Pembinaan Manajemen: Jakarta.

Nazir, M. (2014). Metode Penelitian. Ghalia Indonesia: Bogor.

Pusat Data dan Informasi Pertanian Kementerian Pertanian. 2018.Outlook Komoditas Pertanian Sub Sektor Hortikultura Cabai Merah. Pusat Data dan Sistem Informasi Pertanian, Kementrian Pertanian. Jakarta.

Septiadi, D., \& Nursan, M. (2020). Optimasi Produksi Usaha Tani Sebagai Upaya Peningkatan Pendapatan Petani Sayuran Di Kota Mataram. Agrifo: Jurnal Agribisnis Universitas Malikussaleh, 5(2), 87-96.

Septiadi, D., Sari, N. M. W., Zainuddin, A. (2020). Analisis Permintaan Konsumsi Cabai Rawit pada Rumah Tangga di Kota Mataram. Jurnal Agrimor. 5(2), 36-39.

Suparyana, P. K., FR, A. F. U., \& Ariati, P. E. P. (2020). Motivation Of Dryland Utilization On Integrated Farming In East Lombok. SOCA: Jurnal Sosial Ekonomi Pertanian, 14(2), 351-361. https://doi.org/https://doi.org/10.24843/SOCA.2020.v14.i02.p14

Tanaya, I. G. L. P., Rosmilawati, R., Hidayati, A., \& Septiadi, D. (2021). Analisis Risiko Produksi Spesialisasi Tanaman Hortikultura di Kabupaten Lombok Utara (Analysis of the Risk of Production for Horticultural Specialties in North Lombok Regency). Prosiding SAINTEK, 3, 315-327. 